\title{
Application of Multivariate Statistical Analysis for Valuation of Copyrights in the Hotel Industry
}

\author{
Pawel Kossecki ${ }^{1} \cdot$ Stefan Kossecki $^{2}$
}

Published online: 14 March 2020

(C) The Author(s) 2020

\begin{abstract}
The aim of this work was to identify comparable markets for the hotel industry in Europe and to compare the fees incurred by hotels for using copyrighted and indirect rights for copyright management organizations. The study covers 21 European countries. Using multivariate statistical analysis methods, these countries were grouped, taking into account gross domestic product per capita and the average daily rate for a hotel room. A detailed comparison of the fees that hotels pay for using music and audiovisual works was conducted for the Central and Eastern European countries characterized by the lowest income and hotel prices. The analysis identified wide variation in the methods for calculating fees, fee amounts, and the relationship to hotel revenues among the various countries.
\end{abstract}

Keywords Valuation $\cdot$ Copyrights $\cdot$ Collecting societies $\cdot$ Copyright management organizations $\cdot$ Intangible assets $\cdot$ Hotels

JEL Classification $\mathrm{C} 19 \cdot \mathrm{D} 46 \cdot \mathrm{G} 30 \cdot \mathrm{K} 10 \cdot \mathrm{K} 11 \cdot \mathrm{L} 43 \cdot \mathrm{M} 31$

\section{Introduction}

Royalties paid to societies representing authors, creators and producers are important in many industries, like hotels or gastronomy. There are many disputes and lawsuits

Paweł Kossecki

kossecki@poczta.onet.pl

1 Film Production Department, Polish National School of Film Television and Theater, ul. Targowa 61/63, 90-323 Łódź, Poland

2 Kossecki Tax Planning, ul. Sarmacka 10/39, 02-972 Warszawa, Poland 
related to the fair value of copyrights. The dominant position of collecting societies has resulted in a number of the European Commission decisions as well as judgments of the European Court of Justice (ECJ) and national courts, concerning the activities of collecting societies and the level of fees collected. The problem has been widely analyzed, mainly by law specialists. Recent years have seen an increase in the enforcement of rights related to copyright ownership. People in different countries have protested against the signing of the Anti-Counterfeiting Trade Agreement (ACTA). This process has caused the number of compensation-related court cases for different copyright owners to escalate.

Typical cases in Europe involve the fees paid by hotels and spas to copyright management organizations (CMOs). Some of these cases were judged by the European Court of Justice; in particular regarding CMOs in Spain (ECJ Case C-306/05 2019) and the Czech Republic (ECJ Case C-351/12 2019).

Development of a proper method for calculating the value of copyrights and related rights is an important task in the current climate of the new economy. The hotel industry is a very competitive market and copyright costs are significant. There is a lack of a commonly used and widely accepted methodology to calculate the level of royalties collected by CMOs (Kossecki 2012, 2015). The problem is very serious for many sectors of the economy, where profitability strongly depends on the level of fees paid to collecting societies (discotheques, bars, restaurants, hotels, cable operators, television broadcasters). It also influences the legal security of the companies. The amount of fees has been questioned by both copyright owners and their users, which has led to court cases lasting for years, in Poland.

\section{Methodology Overview}

Valuation of the remuneration of collecting societies is not a typical task for financial analysts and common tools are problematic. Common methods for the valuation of copyrights include market comparison, the income approach and the cost approach (Smith and Parr 2005; Gilbert 2009; Rumniak 2011; Kossecki 2012; Thornton 2013; Pastor et al. 2017).

The cost approach values assets based on the cost of their creation. This approach is not useful for copyrights, because there is a limited correlation between the cost of asset creation and the level of income generated by the asset. The income approach values assets for their ability to generate future income. Usually forecasted income is divided between the licensor and licensee. The income approach was analyzed by Kossecki et al. (2017). Market comparison assumes that free market supply and demand forces will create a so-called equilibrium price. When valuing copyrights, methods based on income and market comparison are preferred. However, only a limited market exists for cases dealing with collecting societies.

Royalties charged to other users cannot be considered market prices, because there is no real market. In some cases, they can be compared to royalties charged in other countries. If the level of fees charged by a copyright collecting society is appreciably higher than the fees charged in comparable foreign markets, it is possible to assume abuse of the dominant position by the collecting society in the market. It is necessary to take the specifics of the geographical markets into consideration. A higher level of 
royalties is associated with a higher level of revenue by copyright users (ECJ Case 395/ 87 2019). When the level of fees charged in different countries is being compared, market characteristics must be considered (Kossecki 2012).

\section{International Comparison Approach}

The difficulties with using market comparisons for calculations of CMO royalties are due to the problem of collecting accurate data in different countries and finding comparable markets. In our analysis, the market comparison methodology supported by taxonomic measures was applied.

It is usually possible to find markets with higher and lower levels of fees collected by CMS. The most important problem is to compare markets with objective criteria. The objective of the investigations presented herein is the recognition and classification of similarities and differences between European countries related to the hotel market. For this purpose, formalism and methods of multivariate comparative statistical analysis were used in the quantitative analysis.

The result of a quantitative comparative analysis is, in general, the appropriate grouping of objects into groups of similar objects, significantly different from objects assigned to other groups. The notion of similarity is connected with the notion of distance between objects. The number of groups and their characteristics are not known in advance. The objective is rather to reveal and classify the existing similarities and dissimilarities. The method of $K$-means (center of gravity method) is described and used in the analysis.

\section{Organization of Data and Clustering Method}

In multivariate statistical analysis, the set of data represents, in general, measurements of many variables related to the set of objects considered. Assume that measurement refers to $m$ variables $(m \geq 2)$. represented by the vector-function:

$$
\boldsymbol{X}=\left[X_{1}, X_{2}, \ldots, X_{m}\right]
$$

Consider now measurements on the set of $n$ objects. Measurement on the object $i$ is to be represented by the point vector $\mathbf{x}_{\mathrm{i}}$ :

$$
\mathbf{x}_{i}=\left\{x_{i 1}, x_{i 2}, \ldots, x_{i m}\right\}, \quad(i=1,2, \ldots, n) .
$$

Measurements on the set of $n$ objects are represented by the $n \times m$ matrix:

$$
\mathbf{X}=\left[x_{i j}\right]
$$

where $x_{i j}$ is the measurement of the $j$-th variable on the $i$-th object.

Measurements of different variables are expressed, in general, in different units. Most multivariate comparative analysis methods may be applied if measurements are given in the same units and are of comparable order. To satisfy this requirement, different normalization procedures are applied. The most common is standardization 
of the variables (Johnson and Wichern 2007):

$$
\begin{gathered}
Z_{j}=\left\{z_{1 j}, z_{2 j}, \ldots, z_{n j}\right\}, \quad(j=1,2, \ldots, m) \\
z_{i j}=\left(\frac{x_{i j}-\bar{x}_{j}}{s_{j}}\right), \quad(i=1,2, \ldots, n ; j=1,2, \ldots, m),
\end{gathered}
$$

where $z_{i j}$ is the standardized value of the variable $X_{j}$ on the $i$-th object, $\bar{x}_{j}$ is the arithmetic average of the variable $X_{j}$, and $s_{j}$ is the standard deviation of the variable $X_{j}$.

The mean value of the standardized variable is zero and its standard deviation is 1 . Standardized data allow us to easily distinguish objects, which are below average or above average with relation to specific variables.

To compare items described by many variables, the notions of similarity and dissimilarity are necessary and must be formally defined. In the multivariate comparative analysis, the measure of dissimilarity is the distance between objects, represented as points in the space of standardized variables. It is called statistical distance (Johnson and Wichern 2007). The most commonly used is the Euclidean distance between objects:

$$
d_{i l}=\sqrt{\sum_{\mathrm{j}=1}^{m}\left(z_{i j}-z_{l j}\right)^{2}}, \quad(i, l=1,2, \ldots, n),
$$

where $d_{i l}$ is distance between objects $i$ and $l$, and $z_{i j}$ is normalized value of the variable $X_{j}$ on the $i$-th object.

\section{$K$-means method}

The idea of the $K$-means method is the partition of a set of objects, represented by points in the space of standardized variables, into subsets (clusters) of similar elements, concentrated around the nearest centroids (means). The term $K$-means was suggested by MacQueen (Johnson and Wichern 2007).

Partitioning into $K$ clusters $C_{k}$ is realized by minimization of the function $G$, which represents overall scattering of points within clusters:

$$
\begin{gathered}
\left\{C_{k}\right\},(k=1,2, \ldots K) \rightarrow \min G \\
G=\sum_{k=1}^{K} \sum i \in C_{k} \sum_{j=1}^{m}\left(Z_{i j}-\gamma_{k j}\right)^{2}
\end{gathered}
$$

where $\gamma_{\mathbf{k}}$ is the point vector representing the mean position of objects assigned to the cluster $C_{k}$; called the center of gravity of the cluster:

$$
\gamma_{k j}=\frac{1}{n_{k}} \sum_{i \in C_{k}} z_{i j}
$$


The function $G$ may be thus represented in the form:

$$
G=\sum_{k=1}^{K} \sum_{i \in C_{k}}\left(g_{i k}\right)^{2}
$$

where $g_{i k}$ is the Euclidean distance between the object $i$, which belongs to the cluster $C_{k}$, and the center of gravity of this cluster.

One-element clusters do not give rise to the value of $G$, as they are centroids themselves. The final number of clusters may be specified in advance or determined as part of the clustering procedure. In what follows, the second approach will be used, as the objective is to identify natural similarities and differences between countries, related to the hotel market.

Finding a partition into clusters that corresponds to the minimum of the overall scattering function is a mathematical task, solved numerically, that usually has a specific solution (one can easily come up with point distributions for which there is no single solution). It is quite another thing is to use such a solution in practice. One may be interested also in partitions which are not much worse than the optimum one, having in mind additional criteria not taken into account in calculations.

\section{Partitioning European Countries into Groups in View of Their Economic Conditions and Hotel Market}

Aggregated data related to the hotel market and main statistics for a group of 21 selected European countries are presented in Table 1. The following basic variables describing the hotel market were considered: gross domestic product (GDP) per capita, average daily rate $(A D R)$, occupancy rate and revenue per available room $(\operatorname{RevPAR})$.

Variables that strongly differentiate countries are GDP per capita and $A D R$ and, to a much lesser extent, occupancy rate. GDP per capita and $A D R$ are not so strongly correlated with each other as one might suppose; the correlation coefficient is 0.616. At the same time, the correlation coefficient for GDP per capita and occupancy rate is 0.582 and for $A D R$ and occupancy rate is only 0.405 . The correlation is weak, but positive, which is not so obvious. RevPAR was calculated as the product of $A D R$ and occupancy rate. It is thus not an independent variable used in the partition procedure.

A number of possible partitions of 21 countries into clusters were examined, using two or three standardized variables. As a preferred solution, discussed later, a partition into four clusters was selected, based only on two variables: GDP per capita and $A D R$. This solution is distinguished by the fact that any reassignment of items significantly increases the overall scattering of points within clusters.

Results of the partition represented as standardized variables are presented in Table 2. Standardized distances between members of particular clusters and cluster centroids are in all cases smaller than distances between centroids, which vary from 1.412 for Clusters 2 and 4 to 4.277 for Clusters 1 and 3. Partitioning to clusters for the original variables is represented in Table 3 . The countries are ordered according to the value of $G D P$ per capita. Distribution of clusters and their centroids on the plane (GDP per capita, $A D R)$ are depicted in Fig. 1. 
Table 1 Basic Parameters Related to the Hotel Market in 21 European Countries

\begin{tabular}{|c|c|c|c|c|c|c|}
\hline No & Country & $\begin{array}{l}\text { Symbol } \\
\text { ISO }\end{array}$ & $\begin{array}{l}\text { GDP per } \\
\text { capita } \\
\text { (EUR) }\end{array}$ & $\begin{array}{l}\text { ADR } \\
\text { (EUR) }\end{array}$ & $\begin{array}{l}\text { Occupancy } \\
\text { Rate }(\%)\end{array}$ & $\begin{array}{l}\text { RevPAR } \\
\text { (EUR) }\end{array}$ \\
\hline 1 & Austria & $\mathrm{AT}$ & 37,600 & 96.38 & 69.7 & 67.18 \\
\hline 2 & Belgium & $\mathrm{BE}$ & 35,100 & 101.59 & 67.1 & 68.17 \\
\hline 3 & Czech Republic & $\mathrm{CZ}$ & 15,400 & 71.96 & 65.7 & 47.28 \\
\hline 4 & Denmark & $\mathrm{DK}$ & 45,200 & 97.89 & 62.6 & 61.28 \\
\hline 5 & Estonia & $\mathrm{EE}$ & 13,600 & 65.55 & 64.0 & 41.95 \\
\hline 6 & Finland & FI & 36,900 & 95.41 & 62.9 & 60.01 \\
\hline 7 & France & FR & 31,800 & 161.95 & 67.8 & 109.80 \\
\hline 8 & Germany & $\mathrm{DE}$ & 34,300 & 94.07 & 66.3 & 62.37 \\
\hline 9 & Greece & GR & 17,300 & 99.93 & 55.4 & 55.36 \\
\hline 10 & Hungary & $\mathrm{HU}$ & 10,000 & 60.26 & 63.6 & 38.33 \\
\hline 11 & Ireland & $\mathrm{IE}$ & 38,300 & 87.45 & 69.6 & 60.87 \\
\hline 12 & Italy & IT & 26,700 & 126.9 & 58.7 & 74.49 \\
\hline 13 & Lithuania & LT & 11,200 & 47.99 & 55.7 & 26.73 \\
\hline 14 & Malta & MT & 17,200 & 94.95 & 69.6 & 66.09 \\
\hline 15 & Netherlands & NL & 38,500 & 106.04 & 65.7 & 69.67 \\
\hline 16 & Poland & PL & 10,100 & 69.72 & 60.5 & 42.18 \\
\hline 17 & Portugal & $\mathrm{PT}$ & 16,000 & 78.32 & 57.7 & 45.19 \\
\hline 18 & Romania & RO & 6700 & 70.32 & 53.6 & 37.69 \\
\hline 19 & Slovakia & SK & 13,400 & 63.49 & 50.7 & 32.19 \\
\hline 20 & Spain & ES & 22,300 & 85.54 & 64.6 & 55.26 \\
\hline \multirow[t]{3}{*}{21} & $\begin{array}{l}\text { United } \\
\quad \text { Kingdom }\end{array}$ & GB & 32,400 & 99.54 & 72.5 & 72.17 \\
\hline & Average & & 24,286 & 89.30 & 63.0 & 56.87 \\
\hline & Standard Deviation & & 11,724 & 24.42 & 5.8 & 18.00 \\
\hline
\end{tabular}

Data sources: STR Global (2013); EUROSTAT (2017)

The compositions of the clusters is as follows. Cluster 1 includes Romania, Hungary, Poland, Lithuania, Slovakia, Estonia, the Czech Republic, and Portugal. Cluster 2 includes Malta, Greece, Spain and Italy. Cluster 3 is France. Cluster 4 includes the United Kingdom, Germany, Belgium, Finland, Austria, Ireland, the Netherlands, and Denmark.

Cluster 1 constitutes seven Central-Eastern European countries and Portugal. All of them show $G D P$ per capita and $A D R$ below the average for the group of 21 European countries. Cluster 2 includes four Mediterranean countries, with a comparatively high $A D R$, but with $G D P$ per capita below or only slightly above the average. Cluster 3 constitutes France by itself which has the highest $A D R$ and a comparatively high GDP per capita. Including France in Cluster 4 increases the overall scattering by more than double. Cluster 4 constitutes eight countries with high GDP per capita and also comparatively high (except Ireland), $A D R$. 
Table 2 Partition of 21 Countries into Four Clusters Using K-means Method; Standardized Variables

\begin{tabular}{|c|c|c|c|c|c|}
\hline Cluster & $\begin{array}{l}\text { Symbol } \\
\text { ISO }\end{array}$ & Country & $\begin{array}{l}\text { GDP per } \\
\text { capita }\end{array}$ & $\begin{array}{l}\text { Average } \\
\text { Daily Rate }\end{array}$ & $\begin{array}{l}\text { Standardized distance } \\
\text { from the centroid }\end{array}$ \\
\hline \multirow{10}{*}{$\mathrm{C}_{1}$} & RO & Romania & -1.500 & -0.777 & 0.490 \\
\hline & $\mathrm{HU}$ & Hungary & -1.218 & -1.189 & 0.291 \\
\hline & PL & Poland & -1.210 & -0.802 & 0.227 \\
\hline & $\mathrm{LT}$ & Lithuania & -1.116 & -1.692 & 0.739 \\
\hline & SK & Slovakia & -0.928 & -1.057 & 0.153 \\
\hline & $\mathrm{EE}$ & Estonia & -0.911 & -0.973 & 0.133 \\
\hline & $\mathrm{CZ}$ & Czech Republic & -0.758 & -0.710 & 0.377 \\
\hline & PT & Portugal & -0.707 & -0.450 & 0.608 \\
\hline & & Centroid 1 & -1.044 & -0.956 & \\
\hline & MT & Malta & -0.604 & 0.232 & 0.421 \\
\hline \multirow[t]{4}{*}{$\mathrm{C}_{2}$} & GR & Greece & -0.596 & 0.435 & 0.315 \\
\hline & ES & Spain & -0.169 & -0.154 & 0.678 \\
\hline & IT & Italy & 0.206 & 1.540 & 1.141 \\
\hline & & Centroid 2 & -0.291 & 0.513 & \\
\hline \multirow[t]{5}{*}{$\mathrm{C}_{3}$} & FR & France & 0.641 & 2.976 & 0.000 \\
\hline & & Centroid 3 & 0.641 & 2.976 & \\
\hline & GB & United Kingdom & 0.692 & 0.419 & 0.427 \\
\hline & $\mathrm{DE}$ & Germany & 0.854 & 0.195 & 0.287 \\
\hline & $\mathrm{BE}$ & Belgium & 0.922 & 0.503 & 0.256 \\
\hline \multirow[t]{6}{*}{$\mathrm{C}_{4}$} & FI & Finland & 1.076 & 0.250 & 0.084 \\
\hline & $\mathrm{AT}$ & Austria & 1.136 & 0.290 & 0.046 \\
\hline & IE & Ireland & 1.195 & -0.076 & 0.412 \\
\hline & $\mathrm{NL}$ & Netherlands & 1.212 & 0.686 & 0.373 \\
\hline & $\mathrm{DK}$ & Denmark & 1.784 & 0.352 & 0.675 \\
\hline & & Centroid 4 & 1.109 & 0.328 & \\
\hline
\end{tabular}

Data sources: STR Global (2013); EUROSTAT (2017)

\section{Copyright Fees on Eight Comparable Markets}

The analysis refers to Cluster 1 which is comprised of eight countries that may be considered as relatively similar with respect to financial relationships in the hotel market. The methodology for calculating the fees that hotels should pay to the CMOs is different in subsequent countries. It is not possible to discuss it in detail in this article. Attention will only be paid to important points. The fees relate primarily to the use of television and radio sets in the hotel rooms and are dependent not only on the category of the hotel, but also on its size (number of available rooms). They may depend also on the occupancy of the rooms and on the period when using an object. Additional fees are charged for playing mechanical music in the background in common spaces as lounges, elevators, corridors or toilets, and depend on whether there is a drink-bar or café in the building. Some discounts may be provided for hotel chains or, for example, in 
Table 3 Basic Parameters Related to the Hotel Market in Four Clusters of European Countries

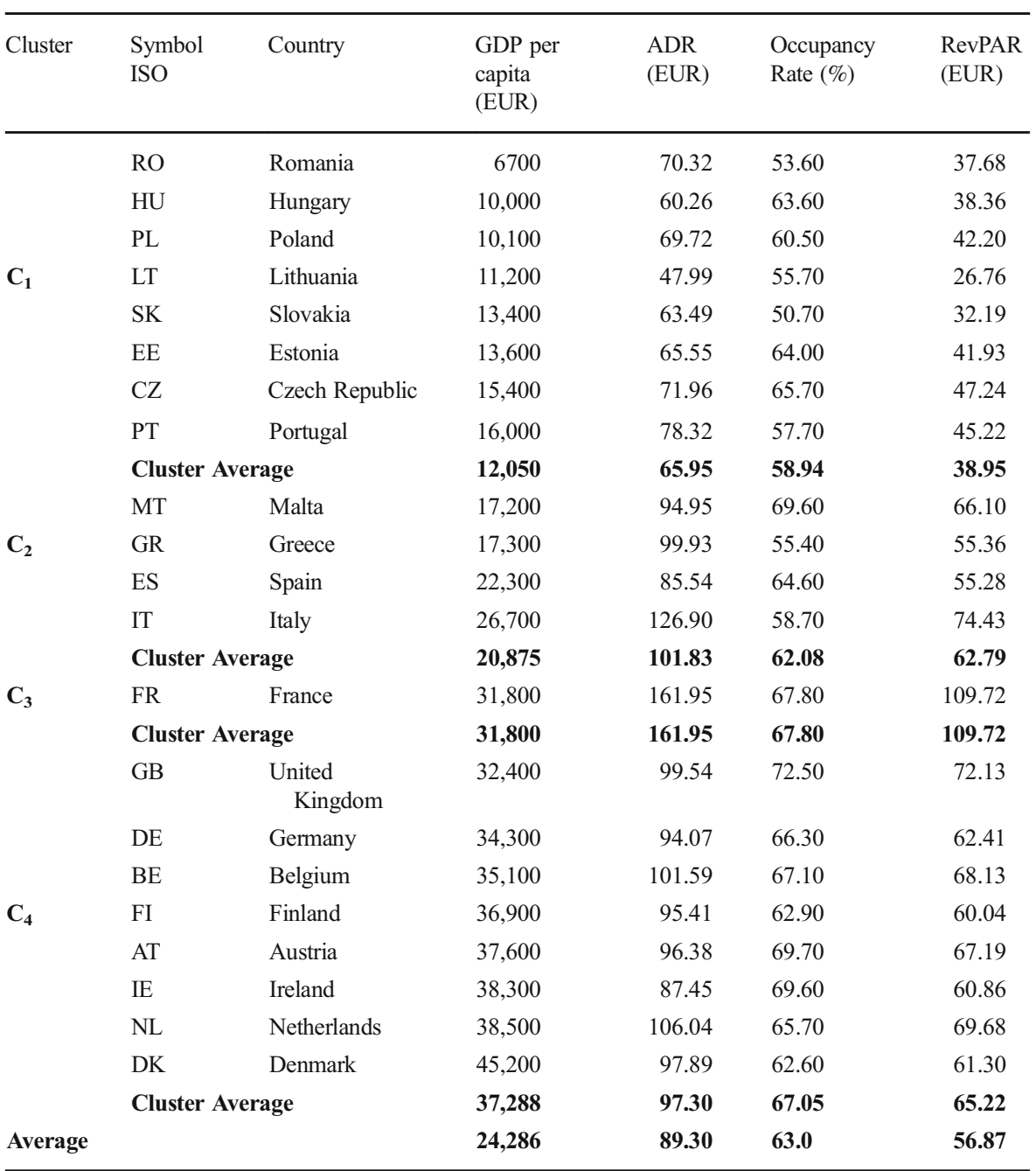

Data sources: STR Global (2013); EUROSTAT (2017)

connection with educational activities. In turn, fee increases may apply to touristattractive towns or in the high season.

Romania: The organizations authorized to collect remuneration on behalf of creators and producers in Romania are: the Romanian Union of Film and Audiovisual Producers, and the Romanian Association for Collective Management of Audiovisual Works (UPFAR - ARGOA 2016) acting together, The Union of Phonogram Producers in Romania (UPFR) and The Romanian Center for Performers' Right Management (CREDIDAM) (UPFR-CREDIDAM 2016). The remuneration tables are set by Romanian Copyright Office (ORDA), the authority subject to the government. The rates depend on the hotel category and number of rooms. 


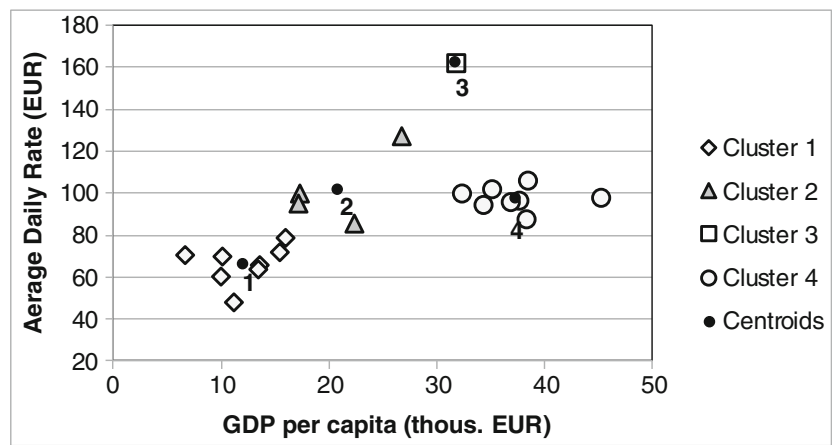

Fig. 1 Average daily rate for a hotel room vs. GDP per capita for 21 European countries. Data sources: STR Global (2013); EUROSTAT (2017)

Hungary: The organization authorized to collect remuneration on behalf of authors, producers of phonograms, performers of music, film producers and performers in film roles is the Hungarian Artists' Association (ARTISJUS 2018). Rates for playing music and for the retransmission of programs, shows and radio and television programs in hotel rooms increase slightly along with the hotel category. Additional fees are provided for playing music in common spaces. The rates are related to the number of rooms $(1-25,26-50,51-100,101-150,151-200, \ldots)$, and significantly decrease with the size of the hotel. The effective remuneration rates are proportional to the average occupancy of hotel rooms for the objects of a given category, published by the Hungarian Central Statistical Office.

Poland: Remuneration tables were developed by the Copyright Commission (KPA) appointed by the government separately for music playback and television use. The rates depend on the category of the hotel, but do not depend on size and current occupancy rate. Certain discounts can be applied for hotel groups, while an increase of $30 \%$ is possible for tourist-attractive towns in full season. The fees are divided accordingly between artists, performers and producers of phonograms and videograms (KPA 2014). (The tables approved by the KPA were appealed by the Chamber of Commerce of the Polish Hotel Industry).

Lithuania: The organizations/associations authorized to collect remuneration on behalf of creators, producers and performers in Lithuania are: LATGA which collectively administers the rights of copyright holders in various fields (music, visual arts, audiovisual art, drama and literature), AGATA which unites performers and music publishers, and Audiovisual Works Copyright Association (AVAKA). Payments to these organizations (per room) related to music reproduction and use of television are related only to the number of rooms in the facility and do not depend on its category. They also depend on the period when using the object (LATGA 2013; AGATA/AVAKA 2016). The fees are much higher than in Estonia.

Slovakia: The organizations / associations authorized to collect remuneration on behalf of creators and producers in Slovakia are: LITA which represents authors of literary works, translators, journalists, directors, script-writers, authors of dramatic and 
music-dramatic works, works visual art and photography, SOZA which represents musical works composers, writers of lyrics and publishers, SLOVGRAM which represents producers of phonograms and audiovisual recordings, collecting fees jointly with OZIS which represents artists-performs and the Slovak Audiovisual Producers Association (SAPA). The fees of all those organizations depend on the hotel category and number of devices for transmission of sound and image of various types. For SOZA, they are the same for categories 1-3. Additional fees apply to common spaces and depend on their area. The effective remuneration rates depend on the billing period (LITA 2016; SOZA 2016; SLOVGRAM 2016; SAPA 2016).

Estonia: The organizations/associations authorized to collect remuneration on behalf of creators, producers and contractors in Estonia are: the Estonian Authors Society (EAU), and, acting together, the Estonian Association of the Phonogram Producers (EFU) and the Estonian Performers Association (EEL). Fees due to EAU and EFU/EEL, related to playing music in common spaces and using televisions in hotel rooms, depend on the number of rooms in the building $(1-50,51-100,101-200 \ldots$ and $1-150,151-200 \ldots$ respectively), but do not depend on the category (EAU 2016; EFU/EEL 2016).

Czech Republic: There are five copyright management organizations authorized to collect remuneration on behalf of authors, contractors and producers: the Copyright Protection Authority for Music Works (OSA), DILIA which is a theater, literary, audiovisual agency, INTERGRAM which is an independent society of performers and producers of phonograms and audiovisual fixations, OAZA which represents authors of phonograms, and OOA-S, which is an association of authors of fine arts, architecture and visual components of audiovisual works. In the area of salary collection for creators, OSA and DILIA associations operate jointly using one table of fees, INTERGRAM, OAZA, and OOA-S operate in a similar way. The rates depend on the number of radio and television sets, the period of their use and the occupancy of the rooms. They do not depend on the size and category of the hotel (OSA 2016; INTERGRAM 2016).

Portugal: The organizations / associations authorized to collect remuneration on behalf of those entitled in Portugal are: PASSMusica which represents artists and performers of musical works, operating jointly with AUDIOGEST which represents phonogram producers, Portuguese Society of Authors (SPA), and GEDIPE/GDA which collects fees jointly for producers of audiovisual works as well as actors, dancers, musicians and their collaborators. The rates set by these associations depend on the number of rooms in the facility and the category. The rates per room slightly decrease with the size of the hotel. The effective remuneration rates depend on the occupancy rates (PASSMusica 2016; SPA 2016; GEDIPE 2016).

Table 4 presents a summary of the total rates for using television and radio sets by the hotels in eight countries. Calculations were performed for the hotels with 20, 50 and 200 rooms. Receivables for all CMOs authorized to collect remuneration in a given country were totaled. The last column shows the percentage differences between the rates for Poland and averages, weighted by GDP per capita, for the remaining seven countries.

The assumptions adopted in the calculations for the countries from the group under consideration are as follows. For all countries, the presence of radio and television sets in rooms and common spaces was assumed. The fees for phonograms and audiovisual works 


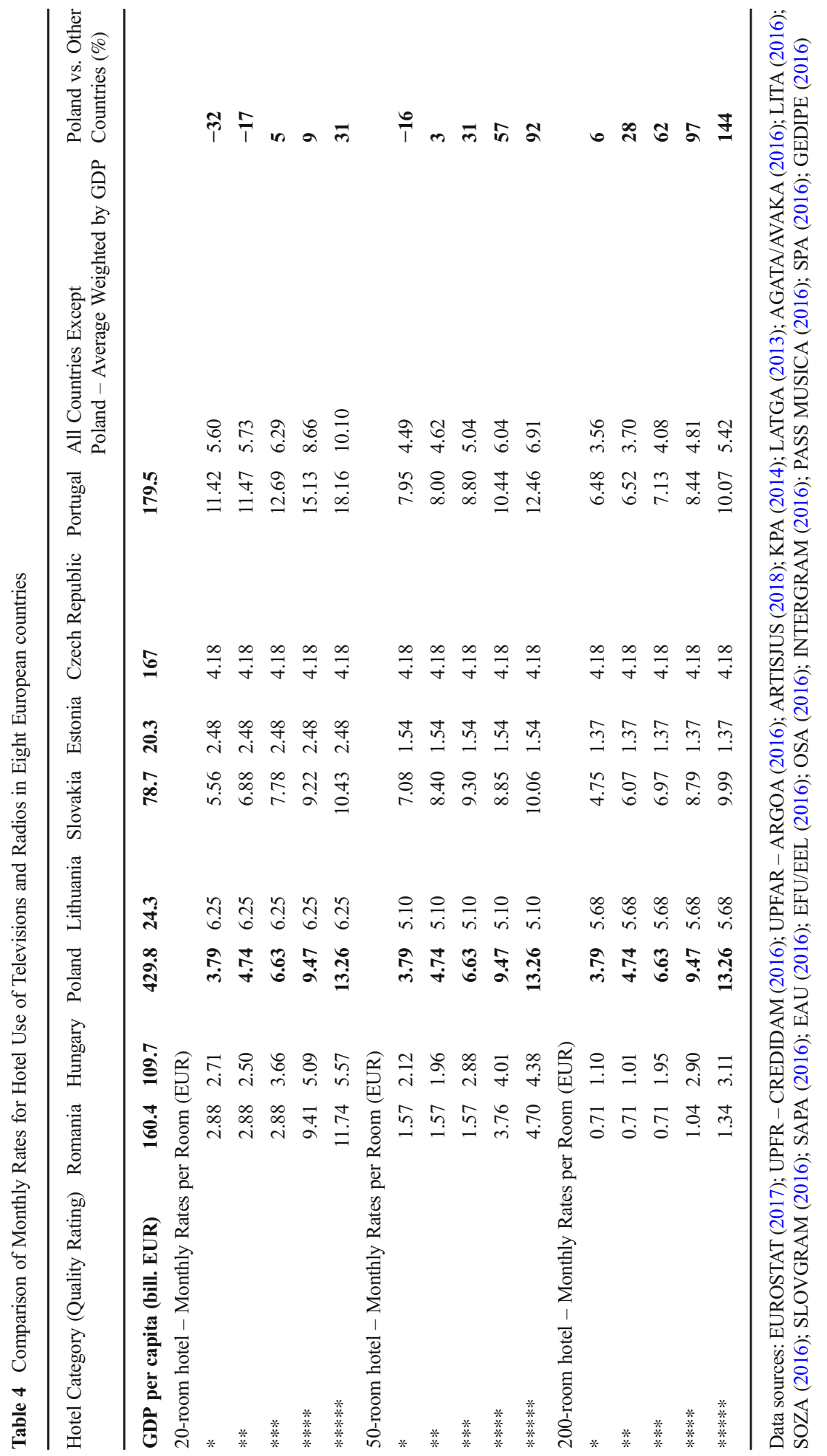


were calculated for radio and television sets together. Discounts that varied across hotels were excluded from the calculations. Exchange rates were calculated based on the average exchange rate of the National Bank of Poland (NBP) for July 1, 2016 (NBP 2016).

For Hungary, music in the background was assumed in one hall for 20-room hotels, for 50-room hotels in one hall and one living-room and for 200-room hotels in two halls and two living rooms as well as in one drink-bar. For Poland, increases in the rates by $30 \%$ for so-called touristic destinations during high season were not taken into account. For Slovakia, the presence of one audio-video set or player in rooms and common spaces was assumed, as was music in lifts and toilets. Payment for additional monitors was excluded. For Slovakia and Lithuania common areas in hotels were estimated based on number of rooms: 20 rooms was up to $100 \mathrm{~m}^{2}, 50$ rooms was up to $200 \mathrm{~m}^{2}$, and 200 rooms was up to $1000 \mathrm{~m}^{2}$. For the Czech Republic, an occupancy rate of 45-79\% was assumed (the level of fees depends on the occupancy rate). For Portugal, all components of fees were included such as background music, pay-perview, music in rooms, and cable television.

Figure 2 presents monthly fees per room for 50-room hotels by hotel quality rating compared with the average monthly revenues per room, calculated using the RevPAR values from Table 1, in subsequent countries. Averages weighted by GDP per capita are included.

Copyright fees to be paid for CMOs by the hotels in Poland are more strongly dependent on the category of an object than in other countries, representing comparable markets. At the same time, no discounts related to the size of the hotel are applied, as in other countries, except the Czech Republic. For hotels with 200 rooms, the fees are higher than the average weighted by GDP per capita, especially for the highest categories, whereas for those with 50 and 20 rooms are lower or the same for low categories and higher for high categories. Therefore, these fees should not be assessed as an abuse of dominant position on the part of collecting societies.

The ratio of monthly rates to average monthly revenues per room can be treated as a very general measure of the ratio of hotel charges to remuneration for CMOs. In countries where fees do not depend on hotel categories, this measure would be just a

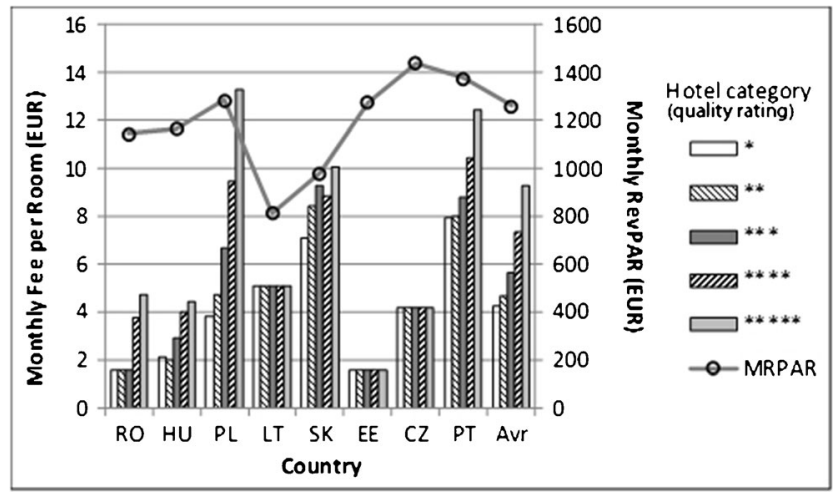

Fig. 2 Monthly fees for CMOs as compared with the average monthly revenues per room for 50-room hotels in eight countries, and averages weighted by GDP per capita. Data sources: STR Global, (2013); EUROSTAT, (2017); UPFR - CREDIDAM (2016); UPFAR - ARGOA (2016); ARTISJUS (2018); KPA (2014); LATGA (2013); AGATA/AVAKA (2016); LITA (2016); SOZA (2016); SLOVGRAM (2016); SAPA (2016); EAU (2016); EFU/EEL (2016); OSA (2016); INTERGRAM (2016); PASS MUSICA (2016); SPA (2016); GEDIPE (2016). 
proportion of those constant fees to average revenues. For 50-room hotels it is appropriately $0.3 \%$ in the Czech Republic, $0.1 \%$ in Estonia, and $0.6 \%$ in Lithuania. For the remaining countries, one may apply a rougher measure, that is, the ratio of the fee averaged over categories to average revenues. Appropriate values would be $0.6 \%$ in Poland, $0.9 \%$ in Slovakia, $0.3 \%$ in Hungary, $0.2 \%$, in Romania, and $0.7 \%$ in Portugal. For 200-room hotels, these percentages would be, in general, significantly lower, whereas for 20-room hotels they would be higher.

However, one should keep in mind that total fees should be compared, not with total revenues, but rather with hotel industry earnings. In Poland, hotel profitability may be approximately $10 \%$, on average and fees may be around $6 \%$ of earnings. When a $30 \%$ increase in tourist destinations is applied, the fees may reach $8 \%$ of earnings, which would be expensive for the hotels, especially when the fees do not depend on the actual occupancy rate.

\section{Conclusions}

In the group of 21 European countries, several subgroups can be distinguished whose members can be considered as comparable markets to the hotel industry. Such subgroups are made up by seven Central-Eastern European countries together with Portugal, four Mediterranean countries, seven Western European countries together with Finland, and France by itself, distinguished by the high prices of hotel rooms.

A detailed analysis of remuneration rates paid by hotels to CMOs for the use of televisions and radios was conducted for the countries of the first subgroup: Romania, Hungary, Poland, Lithuania, Slovakia, Estonia, and the Czech Republic, together with Portugal. In this subgroup of European countries, there is considerable variation in terms of the amount, as well as the criteria for determining the compensation of CMOs for the use of copyright and related rights in hotel facilities.

Remuneration rates for CMOs are relatively high in Slovakia and Portugal, and relatively low in Romania, Hungary and Estonia. In Lithuania and Estonia, the fees depend only on its size and not on the hotel category. In the Czech Republic, the fees do not depend on either the category or size of the hotel.

In Poland, the rates are more heavily dependent on the hotel category than in other countries. However, they are independent of hotel size. A comparison with the rates in other countries shows that rates should not be assessed as an abuse of dominant position on the part of collecting societies.

Remuneration rates paid to CMOs are important for the hotel industry. Although they amount to a small fraction of revenues, with profitability of $10 \%$ they can absorb several percent of earnings. Therefore, it is important to develop principles for their determination that are acceptable to both owners and users.

Open Access This article is licensed under a Creative Commons Attribution 4.0 International License, which permits use, sharing, adaptation, distribution and reproduction in any medium or format, as long as you give appropriate credit to the original author(s) and the source, provide a link to the Creative Commons licence, and indicate if changes were made. The images or other third party material in this article are included in the article's Creative Commons licence, unless indicated otherwise in a credit line to the material. If material is not included in the article's Creative Commons licence and your intended use is not permitted by statutory 
regulation or exceeds the permitted use, you will need to obtain permission directly from the copyright holder. To view a copy of this licence, visit http://creativecommons.org/licenses/by/4.0/.

\section{References}

AGATA/AVAKA (2016). License Fees, agata.lt, https:/www.agata.lt/lt/klientams/tarifai-verslo-erdvems/. Accessed 10 Jan 2019.

ARTISJUS. (2018). http://www.artisjus.hu/wp-content/uploads/2019/01/V19.pdf. Accessed 10 Jan 2019.

EAU. (2016). License Fees. http://www.eau.org/teoste-kasutajale/muusikateoste-avalik-esitus/toitlustus-voimajutusettevotted/. Accessed 10 Jan 2019.

ECJ Case 395/87. European Court of Justice judgment in Ministere Public vs. Tournier. http://curia.europa. eu/juris/showPdf.jsf?text=\&docid=95762\&pageIndex $=0 \&$ doclang $=E N \&$ mode $=1$ st $\&$ dir $=\& o c c=$ first\&part=1\&cid=501712. Accessed 10 Jan 20192019.

ECJ Case C-306/05. European Court of Justice judgment in SGAE vs. RAFAEL Hotels. http://curia.europa. eu/juris/showPdf.jsf?text $=\&$ docid $=66355 \&$ pageIndex $=0 \&$ doclang $=E N \&$ mode $=1$ st $\&$ dir $=\& o c c=$ first\&part=1\&cid=501980. Accessed 10 Jan 20192019.

ECJ Case C-351/12. European Court of Justice judgment in Ochranný svaz autorský pro práva $\mathrm{k}$ dílům hudebním o.s. (OSA) vs. Léčebné lázně Mariánské Lázně a.s. http://curia.europa. eu/juris/document/document.jsf?text=\&docid=148388\&pageIndex=0\&doclang=EN\&mode=req\&dir= \&occ=first\&part=1\&cid=8330064. Accessed 10 Jan 20192019.

EFU/EEL. (2016). License Fees - Agrotourism and other Facilities. http://www.eel.ee/wpcontent/uploads/2016/01/Puhkemajad-tasumäärad.pdf. Accessed 10 Jan 2019.

Eurostat. (2017). GDP and main components - Current prices, https://ec.europa.eu/eurostat/data/database. Accessed 10 Jan 2019.

GEDIPE. (2016). https:/www.gedipe.org/website/tarifas/2016-06-02-16-29-33/simulador-tarifario.html. Accessed 10 Jan 2019.

Gilbert, K. (2009). The valuation of copyright-related intangible assets, insights. Willamette Management Association, Autumn 2009, pp. 35-46.

INTERGRAM. (2016). Payment form for the hotels, http://www.intergram.cz/files/plm2015.pdf. .

Johnson, R. A., \& Wichern, D. W. (2007). Applied multivariate statistical analysis (6th ed.). Englewood Cliffs, NJ: Prentice-Hall.

Kossecki, P. (2012). Metodologia określania wartości praw autorskich - kalkulacja odszkodowań do celów prawnych. E-Mentor, 3(45), 46-50 www.e-mentor.edu.pl/mobi/artykul/index/numer/45/id/934 [in Polish]. Accessed 10 Jan 2019.

Kossecki, P. (2015). Valuation and Value Creation of Cable TV Operators. Cable Retransmissions and Copyright Fees. Polish National Film, television and theater School in Łódź, Łódź.

Kossecki, P., Kossecki, S., Pietrusiński, R. (2017). Assessment of copyright value in hotel industry in Poland: Income approach. Proceedings of 4th International conference on advanced technology and management science, 17-18 Sept 2017, Shenzhen, pp. 194-198. http://dpi-proceedings.com/index. php/dtssehs/article/view/15866. Accessed 10 Jan 2019.

KPA. (2014). Table of remuneration rates for the reproduction of works and related rights. http://bip.mkidn. gov.pl/media/download_gallery/20140424Tabele_z_orzeczeniem_konczacym_postepowanie.pdf [in Polish]. Accessed10 Jan 2019.

LATGA. (2013). License Fees, https://www.latga.lt/uploads/pdf/Tarifai\%20VMKA.pdf\#page=10. Accessed 10 Jan 2019.

LITA. (2016). License Fees, https://lita-web.squarespace.com/s/sadzobnik_dlav.pdf. Accessed 10 Jan 2019.

NBP. (2016). Official Exchange Rates as of 1 July 2016. http://www.nbp.pl/home.aspx?navid=archa\&c= /ascx/tabarch.ascx\&n=a126z160701. Accessed 10 Jan 2019.

OSA. (2016). Tariff of royalties for the use of musical and other copyright works via technical devices-2016. http://www.osa.cz/media/135388/2535en-k(sazebnik\%20r\%20\%202016_final\%20s\%20dilia\%20 od\%201.1.pdf. Accessed 10 Jan 2019.

PASSMusica. (2016). License Tariffs: Hotels, Hostels and Inns, https:/www.passmusica.pt/Licensing. Accessed 10 Jan 2019.

Pastor, D., Glova, J., Lipták, F., \& Kováč, V. (2017). Intangibles and methods for their valuation in financial terms: Literature review. Intangible Capital, 2(13), 387-410 http://www.intangiblecapital.org/index. php/ic/article/view/752/628. Accessed 10 Jan 2019. 
Rumniak, P. (2011). Process approach to intangible assets valuation. Zeszyty Naukowe Uniwersytetu Szczecińskiego, 41(668), 285-294 http://www.wneiz.pl/nauka_wneiz/frfu/41-2011/FRFU-41-285.pdf [in Polish]. Accessed 10 Jan 2019.

SAPA. (2016). License Fees. http://slovakproducers.com/images/181219_sadzobnik_spolocna_sprava_final. pdf. Accessed 10 Jan 2019.

SLOVGRAM. (2016). License Fees. http://www.slovgram.sk/down/Sadzobnik.pdf. Accessed 10 Jan 2019.

Smith, G. V., \& Parr, R. L. (2005). Intellectual property, valuation, exploitation, and infringement damages. Hoboken: John Willey \& Sons.

SOZA. (2016). License Fees, https://moja.soza.sk/cms/content/files/Sadzobník_technické_zariadenia.pdf. Accessed 10 Jan 2019.

SPA. (2016). Public Performance Tariffs 2016, https://www.spautores.pt/usuarios/tabelas. Accessed 10 Jan 2019.

STR Global. (2013). European Hotel Review, https://www.strglobal.com/products/hotel-reviews. Accessed 10 Jan 2019.

Thornton, Grant. (2013). Intangible Assets in a Business Combination: Identifying and valuing intangibles under IFRS 3, https://www.rcgt.com/app/uploads/2017/11/adviser-alert-guide-intangibles-under-ifrs3december-2013.pdf. Accessed 10 Jan 2019.

UPFAR - ARGOA. (2016). License Fees Decision. http://www.orda.ro/fisiere/Decizii\%202013/Decizia\%20 ORDA\%20nr_10\%20-\%202013.pdf. Accessed 10 Jan 2019.

UPFR - CREDIDĀM. (2016). License Fees Decision. http://www.orda.ro/fisiere/2016/Decizii/Decizie\%2010 \%202016.pdf. Accessed 29 Dec 2016.

Publisher's Note Springer Nature remains neutral with regard to jurisdictional claims in published maps and institutional affiliations. 